\title{
EFFECT ON PROPERTIES OF CONCRETE IN PARTIAL REPLACEMENT OF FINE AGGREGATE BY STEEL SLAG AND CEMENT BY METAKAOLIN
}

\author{
R. Padmapriya ${ }^{1, *}$, V.K. Bupesh Raja ${ }^{2,}$, V. Ganesh Kumar ${ }^{3}$ \\ and J.Baalamurugan ${ }^{3}$
}

${ }^{1}$ Department of Civil Engineering, Sathyabama Institute of Science and Technology, Chennai -119, India.

${ }^{2}$ Department of Automobile Engineering, Sathyabama Institute of Science and Technology, Chennai -119, India.

${ }^{3}$ Nanoscience and Materials Chemistry Division, Centre for Ocean Research, Sathyabama Institute of Science and Technology, Chennai -119, India.

*E-mail: padmapriyar_77@yahoo.com

\begin{abstract}
In the present investigation, metakaolin is used to replace a portion of the cement and induction furnace steel slag as partial replacement of fine aggregate in concrete. Metakaolin is a dehydroxylated aluminium silicate pozzolanic material obtained from kaolinite clay mineral. Induction Furnace steel slag is obtained as an industrial by-product during steel production. Hexagonal shaped paver block specimens of side $120 \mathrm{~mm}$ and height $80 \mathrm{~mm}$ are casted. Compressive strength, flexural Strength, split tensile strength, abrasion, water absorption, acid and alkali attack tests were performed. The results show that optimum level replacement of metakaolin (cement) and IF steel slag (fine aggregate) in concrete is $10 \%$ and $20 \%$ respectively.
\end{abstract}

Keywords: Steel Slag, Metakaolin, Concrete, Paver Block, Compressive Strength

(1) RASĀYAN. All rights reserved

\section{INTRODUCTION}

Concrete is being widely used the material in construction because of its unique structural applications such as buildings, industries, residential drainage units, water supply plants and highway infrastructure. Increase of $\mathrm{CO}_{2}$ gas in the environment increases global warming. Cement industries release $\mathrm{CO}_{2}$ while $\mathrm{CaCO}_{3}$ is burnt to produce OPC and hence causes global warming significantly. The research community in the globe is focusing on the development of binders which can be used as an alternate for conventional OPC. ${ }^{1}$ Utilization of metakaolin (MK) as a binding material in mortar/concrete is practice in recent years. $^{2-4}$ The properties of concrete led to greater demand for it and hence the aggregates in it, which occupies almost $3 \backslash 4$ of the total volume of concrete. ${ }^{1}$ The continuous use of natural sand leads to the depletion of river beds results in the ecological imbalance. In order to satisfy the aggregates need in concrete, utilization of industrial by-products are highly encouraged to preserve natural resources., Groundwater pollution increases near solid waste dumping sites and hence solid waste needs to be disposed of/recycled properly to overcome these issues. ${ }^{7}$ Replacement of natural aggregates/binders using industrial by-products and other materials has been continuously emphasized during recent years. ${ }^{8-11}$ Natural coarse/fine aggregate has been partially replaced by steel slag in concrete to avoid industrial byproduct landfilling and natural resource exploitation. ${ }^{12-16}$ The present investigation focuses to utilize metakaolin and IF steel slag in concrete for the partial replacement of cement and fine aggregate respectively.

\section{EXPERIMENTAL}

In the present study materials used are cement, fine aggregate, coarse aggregate, metakaolin, steel slag, and superplasticizer. Mix proportion opted as per IS 10262-2009. ${ }^{17}$

Rasayan J. Chem., 12(4), 1744-1751(2019)

http://dx.doi.org/10.31788/RJC.2019.1245211

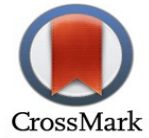




\section{Cement}

Cement is a binding material in construction. It is produced over $1450^{\circ} \mathrm{C}$ by buring cementitious materials. The binder (cement) used in the present study is of specific gravity 3.14 , consistency $32 \%$ and initial setting time $30 \mathrm{~min}$.

\section{Fine Aggregate}

Fine aggregate is the material obtained from rivers called natural sand that will pass through $4.75 \mathrm{~mm}$ sieve. The fine aggregate fills the voids of coarse aggregate and improves the workability. The specific gravity of fine aggregate used is 2.6 and the fineness modulus is 3.45 which conforms to zone III of IS 383.

\section{Coarse Aggregate}

In the present study coarse aggregate of size 10 to $12.5 \mathrm{~mm}$ was used and the specific gravity is 2.71 .

\section{Metakaolin}

Metakaolin is a pozzalonic characteristic material and can be used for the partial replacement of cement. Figure-1 shows the metakaolin used. The specific gravity of metakaolin used in the present study is 3.1.

\section{Steel Slag}

Steel slag is an industrial by-product and is obtained from the steel manufacturing process. In the present study natural fine aggregate is partially replaced by Induction furnace steel slag. Figure- 2 shows the Induction furnace steel slag used. The specific gravity is 2.6

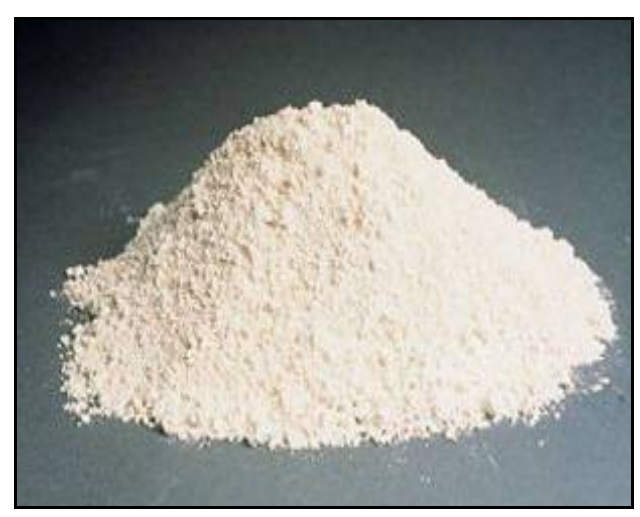

Fig.-1: Metakaolin

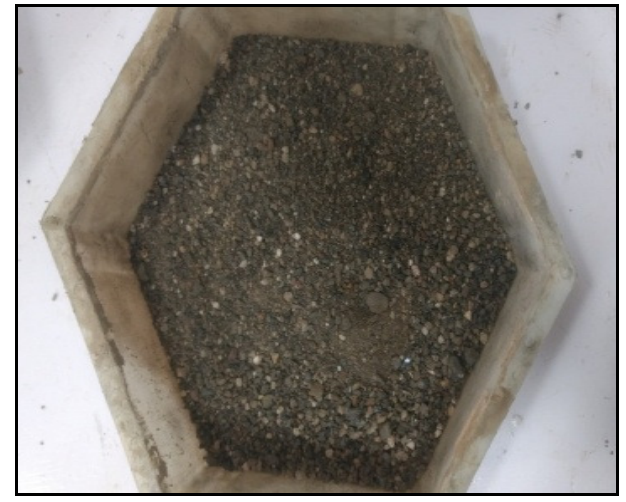

Fig.-2; Induction Furnace Steel Slag

\section{Optimization of Steel Slag}

As per IS 15658:2006 concrete grade chosen in the present investigation is $\mathrm{M}_{35}$ for Light traffic. ${ }^{18}$ Optimum replacement of Induction furnace steel slag was found for 28 days strength of concrete cubes of size 150x150x150 mm. Concrete cubes were cast for $\mathrm{M}_{35}$ grade by varying fine aggregate with Induction furnace steel slag by $0 \%, 20 \%, 40 \%, 60 \%$, and $80 \%$. Six cubes for each replacement ratio were cast as shown in Fig.-3 and tested for 28 days compressive strength. The optimized level of replacement of IF steel slag as fine aggregate is $20 \%$.

\section{Casting of Paver Blocks}

Totally 96 hexagonal shaped paver blocks of side $120 \mathrm{~mm}$, thickness $80 \mathrm{~mm}$ were cast and cured in room temperature and tested. The paver blocks were cast into four groups, M1 (0\% metakaolin), M2 (10\% metakaolin), M3 (20\% metakaolin), and M4 (30\% metakaolin) based on the percentage of metakaolin added. Fine aggregate was replaced by $20 \%$ steel slag for all the percentages of metakaolin. The paver block is in a hexagonal shape. Also, 8 numbers of cubes of $7 \mathrm{~cm} \times 7 \mathrm{~cm} \mathrm{x} 7 \mathrm{~cm}$ were cast for abrasion test. Fig. -4 shows the casted paver blocks. 


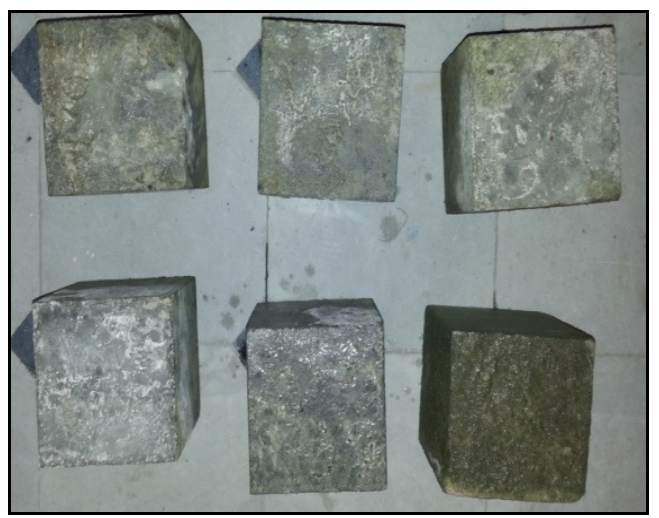

Fig.-3: Cubes for Optimisation of Steel Slag

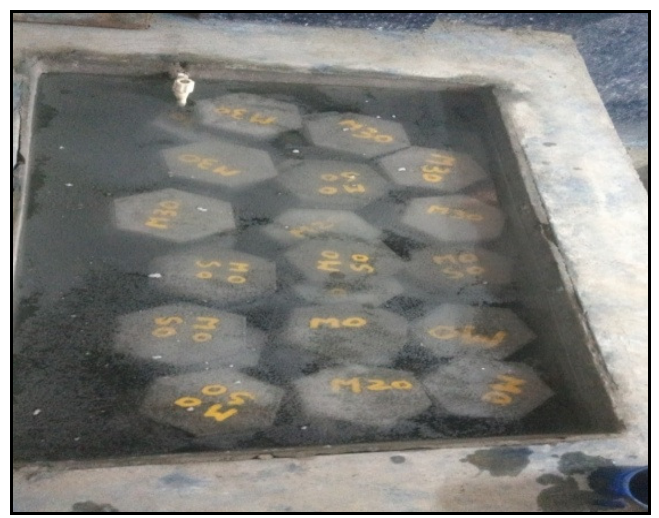

Fig.-4: Casted Paver Blocks

\section{Testing of Paver Blocks \\ Compressive Strength Test}

Figure-5 shows the compression strength performed for the prepared specimens. All the specimens are tested in a saturated condition, after drying the surface of the specimen containing no moisture in it. For each mix proportion, cubes are tested for 7 days, 14 days and 28 days using $3000 \mathrm{KN}$ compression testing machine as per IS 516:2009. The tests are carried out at a uniform rate stress level with the specimen property placed and centered in the testing machine. Loading applied gradually with the help of hydraulic pumps until the dial gauge get reverses its direction of motion. The reversal of needle indicates the total failure, the ich is the ultimate failure load of the specimen. The tested specimen is given below:

Compressive strength $=\mathrm{P} / \mathrm{A}$

Where, P - Failure load $(\mathrm{N})$; A - Area of the specimen $\left(\mathrm{mm}^{2}\right)$

\section{Split Tensile Strength}

Prepared specimens were tested for its split tensile strength (Fig.-6). The test has been performed as per standard protocols with the splitting tension stress range of 0.7 to $1.3 \mathrm{Mpa}$. The splitting tensile strength is computed from the formula according to IS 5816:1999. The tested specimen is given below,

$$
\mathrm{T}=2 \mathrm{P} / \pi \mathrm{ld}^{2}
$$

Where, $\mathrm{T}$ - Tensile strength $\left(\mathrm{N} / \mathrm{mm}^{2}\right)$; $\mathrm{P}$ - Failure load $(\mathrm{N}) ; 1$ - Length of the specimen $(\mathrm{mm})$; $\mathrm{d}$ - Diameter of the specimen $(\mathrm{mm})$

\section{Flexural Strength Test}

Flexural strength of specimens prepared was tested is shown is Fig.-7. Simple beam loading is applied from the top of the specimen via a roller of diameter $25 \mathrm{~mm}$. The roller is placed exactly between the supporting rollers at the bottom and the load is applied without shock. The failure load (maximum load) is recorded. Flexural strength is calculated using the following formulae,

$$
\mathrm{R}=3 \mathrm{pl} / 2 \mathrm{bd}^{2}
$$

Where, $\mathrm{P}$ - maximum load $(\mathrm{N}) ; 1$ - span length $(\mathrm{mm}) ; \mathrm{b}$ - specimen width $(\mathrm{mm}) ; \mathrm{d}$ - specimen depth $(\mathrm{mm})$

\section{Water Absorption Test}

The prepared specimens were immersed in water for 28 days after the drying process. Specimens are weighed before and after immersion in water. The percentage of water absorption has been calculated using the following formulae:

Percentage of water absorption $=\left(\mathrm{w}_{\mathrm{d}}-\mathrm{w}_{\mathrm{w}} / \mathrm{w}_{\mathrm{d}}\right) * 100$ 
Where, $\mathrm{w}_{\mathrm{w}}=$ weight of specimen immersed in water $(\mathrm{kg})$

$\mathrm{w}_{\mathrm{d}}=$ weight of specimen before immersing in water $(\mathrm{kg})$

\section{Acid Attack Test}

Figure- 8 shows the acid attack test of specimens prepared (28 days). Alkaline nature of the concrete block is expected to undergo acid attack when in contact with acid. Sulphuric acid of 5\% is used for acid attack test. The percentage of an acid attack has been calculated using the below formulae:

Percentage of acid attack $=\left(\mathrm{w}_{\mathrm{d}}-\mathrm{w}_{\mathrm{ac}} / \mathrm{w}_{\mathrm{d}}\right) * 100$

Where, $\mathrm{w}_{\mathrm{ac}}=$ weight of specimen immersed in the acid solution $(\mathrm{kg})$ $\mathrm{w}_{\mathrm{d}}=$ weight of specimen before immersing in acid solution $(\mathrm{kg})$

\section{Alkali Attack Test}

Sodium hydroxide is used as an alkali for the present study. Specimens were immersed in $4 \%$ of sodium hydroxide solution for 28 days (Fig.-9) and the alkali attack has been calculated using the below formulae:

Percentage of alkali attack $=\left(\mathrm{w}_{\mathrm{d}}-\mathrm{w}_{\mathrm{al}} / \mathrm{w}_{\mathrm{d}}\right) * 100$

Where, $\mathrm{w}_{\mathrm{al}}=$ weight of specimen immersed in alkali solution $(\mathrm{kg})$

$$
\mathrm{w}_{\mathrm{d}}=\text { weight of specimen before immersing in alkali solution }(\mathrm{kg})
$$

\section{Abrasion Test}

Three cubes of $7 \mathrm{~cm} \times 7 \mathrm{~cm} \times 7 \mathrm{~cm}$ were casted in each mix and cured in room temperature for 28 days. The initial dry weight of the cubes is noted. Abrasion test has been carried out as per standard protocols for the specimens prepared (Fig.-10). Abrasion of the specimen prepared has been calculated after 25 cycles using the following formulae,

$$
\Delta \mathrm{V}=\Delta \mathrm{m} / \mathrm{PR}
$$

Where, $\Delta \mathrm{V}-$ loss in volume $\left(\mathrm{mm}^{3}\right)$

$\Delta \mathrm{m}-$ loss in mass $(\mathrm{g})$

$\mathrm{PR}$ - specimen density $\left(\mathrm{g} / \mathrm{mm}^{3}\right)$

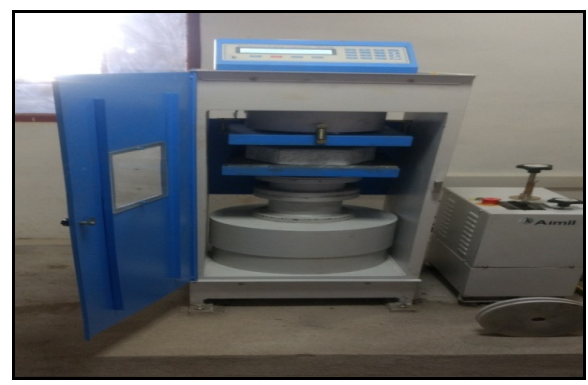

Fig.-5: Compressive Strength Test

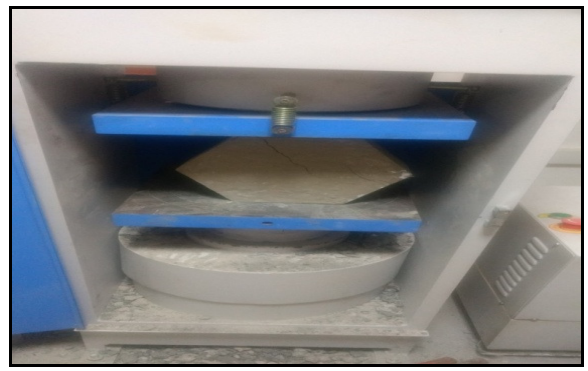

Fig.-7: Flexural Strength Test

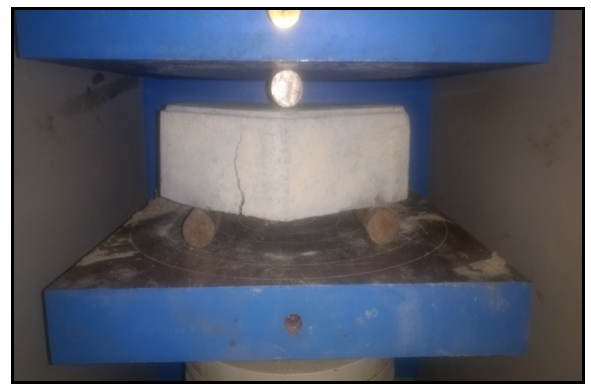

Fig.-6: Split Tensile Strength

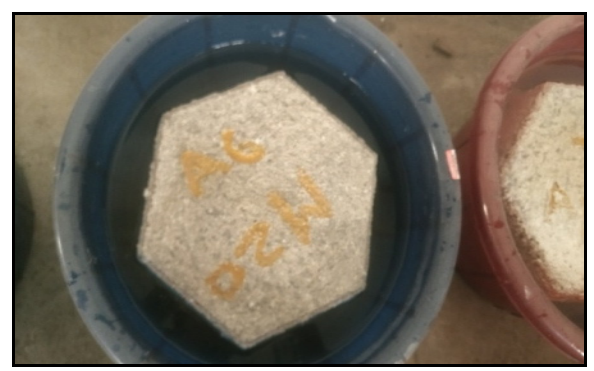

Fig.-8: Acid Attack Test 
RASĀYAN J. Chem.

Vol. 12 | No. 4 |1744 - 1751| October - December | 2019

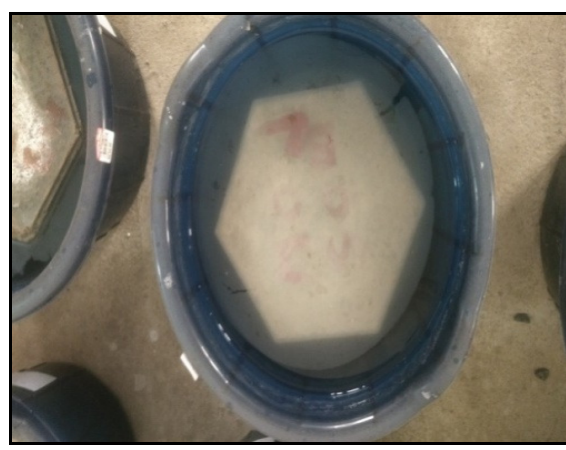

Fig.-9: Alkali Attack Test

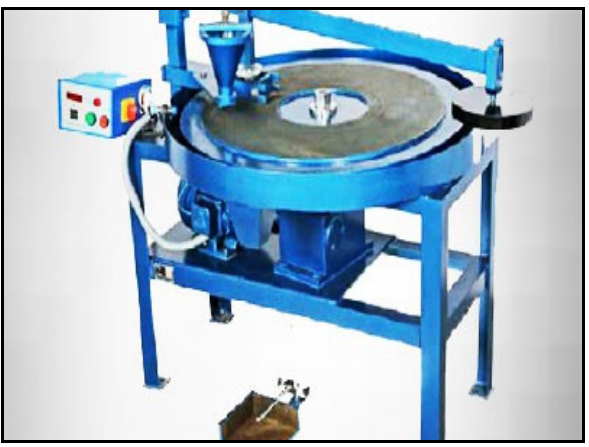

Fig.-10: Abrasion Test

\section{Compressive Strength}

\section{RESULTS AND DISCUSSION}

The casted paver blocks have been tested and the compressive strength test results are shown in Fig.- 11 . Compression strength is maximum for the M2 (10\% Metakaolin) paver blocks. This indicates that compression strength decreases with the addition of metakaolin.

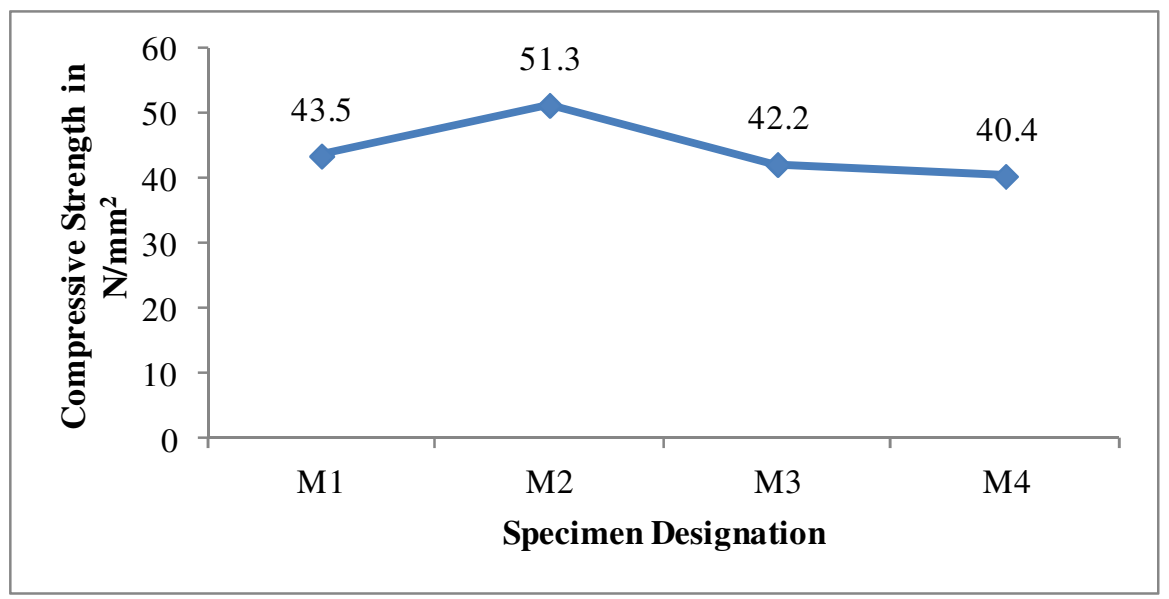

Fig.-11: Compressive Strength

\section{Spilt Tensile Test}

The paver blocks have been tested and split tensile test results are shown in Fig.-12. The split tensile strength is maximum for M2(10\% metakaolin) paver blocks.

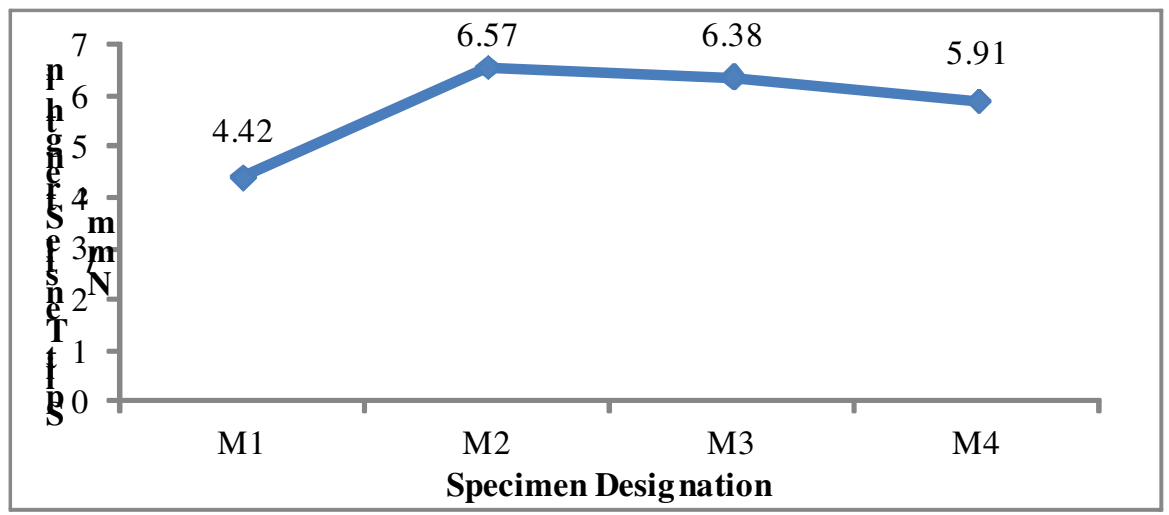

\section{Flexural Strength}

Fig.-12: Split Tensile Test

The paver blocks have been tested and the flexural test results are shown in Fig.-13. Flexural strength is maximum for the M2 paver blocks. 
RASĀYAN J. Chem.

Vol. 12 | No. 4 |1744 - 1751| October - December | 2019

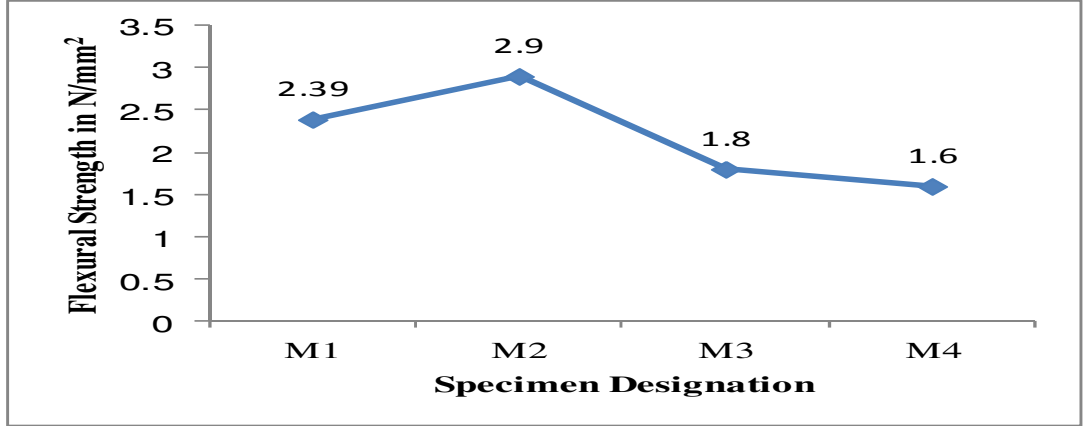

Fig.-13: Flexural Strength

\section{Acid Attack Test}

The paver blocks are immersed in 5\% sulphuric acid and the percentage of acid attack is shown in Table1.

Water Absorption Test

The paver blocks are immersed in water for 28 days and the percentage absorption of water is tabulated in Table-2.

Table-1: Acid Attack in Percentage (\%)

\begin{tabular}{c|c|c|c}
\hline S .No. & $\begin{array}{c}\text { Specimen } \\
\text { designation }\end{array}$ & $\begin{array}{c}\text { Percentage of } \\
\text { metakaolin added }\end{array}$ & $\begin{array}{c}\text { Percentage of water } \\
\text { absorption }\end{array}$ \\
\hline 1 & M1 & $0 \%$ & 0.87 \\
\hline 2 & M2 & $10 \%$ & 1.26 \\
\hline 3 & M3 & $20 \%$ & 1.1 \\
\hline 4 & M4 & $30 \%$ & 1.18 \\
\hline
\end{tabular}

\section{Alkali Attack Test}

The paver blocks have been immersed in $4 \%$ sodium hydroxide and the percentage absorption of alkali is tabulated in Table-3.

\section{Abrasion Test}

The cubes of side $7 \mathrm{~cm}$ were casted and tested for abrasion. The abrasive wear of the specimen after 25 cycles of testing shall be calculated as the mean loss in specimen volume $(\Delta \mathrm{V})$ and is shown in Table- 4 . It was found that loss in volume is maximum for M2 specimen.

Table-2: Water Absorption in Percentages (\%)

\begin{tabular}{c|c|c|c}
\hline S .No. & $\begin{array}{c}\text { Specimen } \\
\text { Designation }\end{array}$ & $\begin{array}{c}\text { Percentage of } \\
\text { Metakaolin } \\
\text { Added }\end{array}$ & $\begin{array}{c}\text { Percentage of } \\
\text { Acid Attack }\end{array}$ \\
\hline 1 & M1 & $0 \%$ & 1.96 \\
\hline 2 & M2 & $10 \%$ & 2.1 \\
\hline 3 & M3 & $20 \%$ & 2.04 \\
\hline 4 & M4 & $30 \%$ & 2.08 \\
\hline
\end{tabular}

Table-3: Alkali Attack Test in Terms of Percentage (\%)

\begin{tabular}{c|c|c|c}
\hline S. No. & $\begin{array}{c}\text { Specimen } \\
\text { Designation }\end{array}$ & $\begin{array}{c}\text { Percentage of } \\
\text { Metakaolin Added }\end{array}$ & $\begin{array}{c}\text { Percentage of } \\
\text { Alkali Attack }\end{array}$ \\
\hline 1 & M1 & $0 \%$ & 2.10 \\
\hline 2 & M2 & $10 \%$ & 2.2 \\
\hline 3 & M3 & $20 \%$ & 2.17 \\
\hline 4 & M4 & $30 \%$ & 2.0 \\
\hline
\end{tabular}




\section{High-Resolution Scanning Electron Microscope (HR SEM) Analysis}

HR-SEM analysis of metakaolin is shown in Fig.-14. The particles in metakaolin are mostly hexagonal in shape with some pentagonal shaped particles and have no sharp edges which enhance binding of the material. The size of the majority of the particles present in metakaolin is ranging from 100 to $250 \mathrm{~nm}$. The smaller size of the particles present in metakaolin improves binding which increases the strength of the concrete blocks.

EDAX analysis of metakaolin is tabulated in Table-5. The elements present in metakaolin are in oxide form. Silicon, aluminum and magnesium are the major elements present in metakaolin with $32.22 \%$, $25.57 \%$ and $1.06 \%$ by weight percentage.

Table-4: Abrasive Wear Resistance

\begin{tabular}{c|c|c|c}
\hline S.No. & $\begin{array}{c}\text { Specimen } \\
\text { Designation }\end{array}$ & $\begin{array}{c}\text { Percentage of } \\
\text { Metakaolin } \\
\text { Added }\end{array}$ & $\begin{array}{c}\text { Loss in Specimen } \\
\text { Volume }\left(\mathrm{mm}^{3}\right)\end{array}$ \\
\hline 1 & M1 & $0 \%$ & 1020 \\
\hline 2 & M2 & $10 \%$ & 1050 \\
\hline 3 & M3 & $20 \%$ & 1040 \\
\hline 4 & M4 & $30 \%$ & 1000 \\
\hline
\end{tabular}
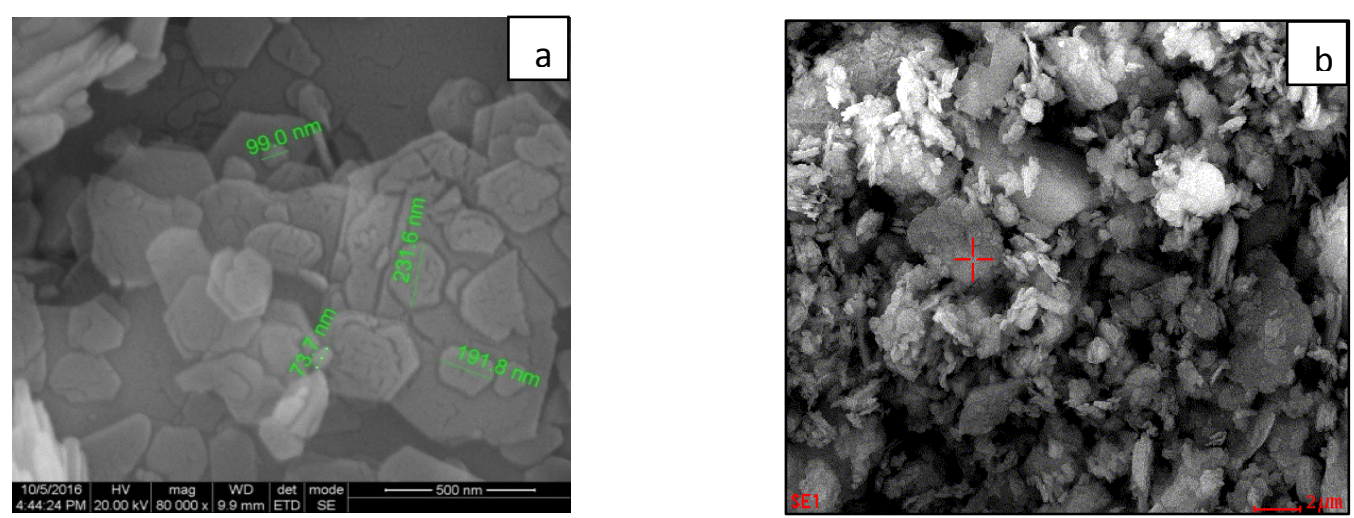

Fig.-14: Morphology of Metakaolin Table-5: Elements Present in Metakaolin

\begin{tabular}{c|c|c}
\hline Elements & Wt \% & At \% \\
\hline $\mathrm{OK}$ & 41.15 & 54.60 \\
\hline $\mathrm{MgK}$ & 1.06 & 0.93 \\
\hline $\mathrm{AlK}$ & 25.57 & 20.12 \\
\hline $\mathrm{SiK}$ & 32.22 & 24.35 \\
\hline Matrix & Correction & $\mathrm{ZAF}$ \\
\hline
\end{tabular}

X-Ray Diffraction (XRD) Analysis

The XRD results are shown in Figure-15.
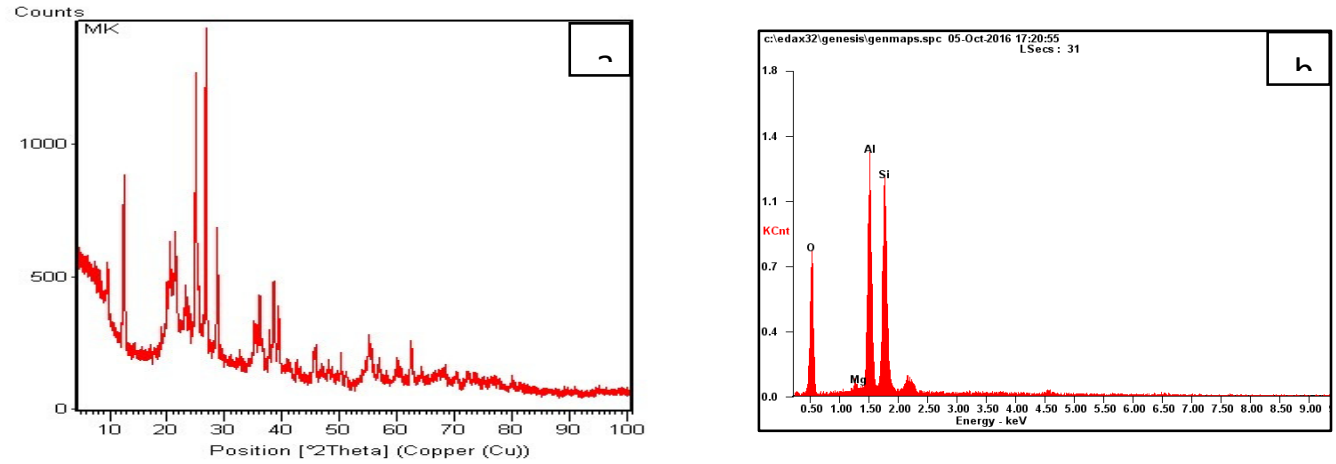

Fig.-15: XRD Analysis 
In XRD analysis the major peak values of metakaolin correspond to $2 \varphi$ values are $16,27,29,32,36$, and 39 . The JCPDS values of the metakaolin utilized in the present study correspond to 50-1333.

\section{CONCLUSION}

The increased strength is obtained by replacing cement by metakaolin up to $10 \%$ and steel slag as $20 \%$ constant for all mixes. Due to shape size and surface texture of steel slag aggregate and also by the nature of the metakaolin which provides better adhesion between the particles and cement mix. The optimum level of replacement for metakaolin is found as $10 \%$ and increase in strength initially and decreases in strength beyond $10 \%$.

\section{REFERENCES}

1. N. Palankar, A.U. Ravi Shankar, B.M. Mithun, Journal of Cleaner Production, 129, 1(2016), DOI: $10.1016 /$ j.jclepro.2016.04.033

2. M.S. Morsy S.H. Alsayed Y.A. Salloum, Construction and Building Materials, 35, 772(2012), DOI:10.1016/j.conbuildmat.2012.04.142

3. F. Cassagnabere, M. Mouret, G. Escadeillas, P. Broilliard, A. Bertrand, Construction and Building Materials, 24(7), 1109(2010), DOI:10.1016/j.conbuildmat.2009.12.032

4. I. Dojkov, S. Stoyanov, J. Ninov, B. Petrov, Journal of Chemical Technology and Metallurgy, 48(1), 54(2013)

5. A.M Rashad, D.M Sadek, H.A. Hassan, Journal of Cleaner Production, 112(1), 1086(2016), DOI:10.1016/j.jclepro.2015.07.127

6. P. Nuaklong, V. Sata, P. Chindaprasirt, Journal of Cleaner Production, 112(4), 2300(2013), DOI:10. 1016/j.jclepro.2015.10.109

7. P. Vijayalakshmi, M. Abraham, Rasayan Journal of Chemistry, 11(2), 728(2018), DOI: 10.7324/RJC.2018.1122051

8. M. Kavisri, P. Senthilkumar, M.S Gurukumar, K.J Pushparaj, Rasayan Journal of Chemistry, 11(1), 111(2018), DOI:10.7324/RJC.2018.1111805

9. N. Parthasarathi, M. Prakash, K.S Satyanarayanan, Rasayan Journal of Chemistry, 10(2), 442(2017), DOI:10.7324/RJC.2017.1021689

10. K. Divya Krishnan, P.T Ravichandran, V.K Gandhimathi, Rasayan Journal of Chemistry, 10(2), 600(2017), DOI:10.7324/RJC.2017.1021677

11. S. Prakash Chandar, K. Gunasekaran, K.Prasanth and G.Senthilkumar, Rasayan Journal of chemistry, 11(2), 702(2018), DOI:10.7324/RJC.2018.1123003

12. R. Padmapriya, V.K Bupeshraja, V. Ganesh Kumar, J. Baalamurugan, International Journal Of Chem tech Research, 8(4), 1721(2015).

13. J. Baalamurugan, V. Ganesh Kumar, S. Chandrasekaran, S. Balasundar, B. Venkatraman, R. Padmapriya, V.K. Bupesh Raja, Journal of Hazardous Materials, 369(5), 561(2019), DOI: 10.1016/j.jhazmat.2019.02.064

14. K. Chinnaraju, V.R.Ramkumar, K.Lineesh, S.Nithya, V.Sathish, International Journal Of Research In Engineering And Advanced Technology, 1(3), 1(2013)

15. M. Sounder rajan, International Journal on Engineering Technology And Science, 1(6), 96(2014)

16. R. Padmapriya, V.K. Bupesh Raja , V. Ganesh Kumar, J.Baalamurugan, International Journal Of Earth Sciences and Engineering, 8(5), 2116(2015)

17. IS 10262-2009 Indian Standard Concrete Mix Proportion

18. IS 15658-2006 Indian Standard Precast Concrete Blocks For Specimen

[RJC-5211/2019] 